ОБГРУНТУВАННЯ ЗНАЧЕННЯ МЕТОДИКИ “СДИНОГО ДНЯ" ДЛЯ ТЕОРЕТИЧНОЇ ТА ПРАКТИЧНОЇ ПІДГОТОВКИ СТУДЕНТІВ У ВИВЧЕННІ ІНОЗЕМНОЇ ПРОФЕСІЙНОЇ МЕДИЧНОЇ ЛЕКСИКИ

Р. Б. Коцюба

ДВНЗ “Тернопільський держсавний медичний університет імені І. Я. Горбачевського МОЗ Украӥни”

\author{
THE SIGNIFICANCE SUBSTANTIATION OF THE “ONE DAY" \\ EDUCATIONAL METHODS FOR THE THEORETICAL AND PRACTICAL \\ TRAINING OF STUDENTS IN LEARNING THE FOREIGN \\ PROFESSIONAL MEDICAL TERMINOLOGY
}

R. B. Kotsyuba

SHEI "Ternopil State Medical University by I. Ya. Horbachevsky of MPH of Ukraine”

\begin{abstract}
У статті обгрунтовується ефективність використання методики “Сдиного дня" для теоретичної та практичної підготовки студентів у вивченні іноземної професійної медичної лексики.

The article adduces the significance of the "One Day" educational methods for the theoretical and practical training of foreign students in learning the foreign professional medical terminology.
\end{abstract}

Вступ. Сучасний етап розвитку українського суспільства характеризується виведенням освіти в Україні на рівень розвинутих країн світу. А це передбачає впровадження у навчальний процес сучасних педагогічних та наукових інновацій відповідно до світових стандартів.

Навчання іноземної мови було й залишається невід'ємною складовою процесу формування сучасного фахівця. Щодо значимості виконання соціального замовлення свідчить той факт, що показник рівня володіння іноземною мовою включений у кваліфікаційну характеристику випускника вузу.

Більш того, новітня європейська мовна політика орієнтує громадян Європи на багатомовність. Без цього успішна інтеграція в сучасному світі просто неможлива. Вивчення в навчальних закладах більш ніж однієї іноземної мови, безумовно, знаходиться в інтересах загальної національної політики України.

Формування сучасної моделі підготовки спеціалістів вимагає нового підходу до організації навчального процесу.

Починаючи з 2006 року, у Тернопільському державному медичному університеті імені І. Я. Горбачевського була запроваджена методика "Сдиного дня". Оскільки дана методика як експериментальна застосовується на території України тільки у ТДМУ, і $є$ запозиченою на основі вивчення досвіду європейської та американської медичної освіти у чотирьох вищих навчальних закладах Свропи: Віденському, Братиславському, Празькому університетах, у Шльонській медичній академії та двох університетах США у штатах Південна Кароліна та Каліфорнія [5], то можна зробити висновок, що проблема організації навчального процесу в аспекті його часово-просторового виміру недостатньо вивчена, і не тільки в медичній освіті.

Мета даної роботи - обгрунтувати ефективність використання методики “Є Синого дня" для теоретичної та практичної підготовки студентів-іноземців у вивченні іноземної професійної термінології.

Основна частина. При обгрунтуванні ефективності методик, які стосуються часово-просторової організації занять, ми виділяємо ряд таких факторів, як: психологічний, лінгвістично-педагогічний, методико-педагогічний та економічний.

Психологічний фактор. При дослідженні помічено, що ефективність проведення занять та опанування студентами мовних дисциплін на заняттях, які йдуть безпосередньо після клінічних дисциплін, суттєво втрачається. Оскільки студентам дуже важко перелаштуватися 3 медичної дисципліни на мовну, втрачається ефективність запам'ятовування та

() Р. Б. Коцюба 
відтворення пройденого матеріалу, дуже важко відбувається переключення уваги з одного матеріалу на інший, адже медичні дисципліни кардинально відрізняються від мовних. При швидкій зміні предметів 3 різних галузей знань знижується рівень зосередження на зорових, слухових та інших видах подразників. Також знижується довільність і стійкість уваги, а, як наслідок, і пізнавальна активність студентів [3]. Методика “Сдиного дня" сприяє активній роботі студента на заняттях, підвищує увагу та покращує навчальну діяльність студента.

Дана методика за рахунок наявності більшої кількості часу підвищує довільність запам'ятовування, формує навички осмисленого запам'ятовування словесного матеріалу, розвиває вміння відтворювати вивчений матеріал, розвиває короткочасну оперативну пам' ять і формує у студентів моторно-слуховий тип запам'ятовування.

Внаслідок системно проведених занять і активної участі студентів можна досягнути максимального ефекту, тобто покращити рівень розвитку пам'яті, що сприятиме ефективності навчальної діяльності і успішному відтворенню вивченого матеріалу на іспитах.

Завдяки даній методиці відсутнє розсіювання уваги, студенти зосереджуються на одному виді діяльності, при якому знижується рівень зовнішніх подразників [4].

При проведенні як мовних, так і клінічних дисциплін 3'являється можливість проведення тренінгових занять у колі, в комфортному для студентів середовищі, де долаються комунікативні бар'єри, розвивається перцепція, комунікабельність та інтеракція. Також відбувається розвиток мовної комунікабельності [3].

Лінгвістично-педагогічний фактор

У той же час проблеми, пов'язані з викладанням іноземної медичної мови для студентів у медичному вузі, вимагають новітнього оптимізаційного підходу до часово-просторової організації навчального процесу зі структурними змінами в робочій програмі, що передбачають інтегроване вивчення споріднених тем і розділів.

Долати вищенаведені проблеми допомагає методика “Сдиного дня”. Протягом одного навчального дня студенти мають можливість не просто грунтовно оволодіти матеріалом, що стосується окремої теми, а можуть опрацювати, вдосконалити знання 3 вивченого матеріалу в різних ігрових ситуаціях, що дає можливість сформувати у студентів уміння та навички, які дадуть їм змогу взяти участь у професійному мовленнєвому спілкуванні: звернутись до молодшого медичного персоналу, медсестри, хворо- го, уміти запитати про скарги, дати відповідні рекомендації [2].

\section{Методико-педагогічний фактор}

Дана методика передбачає повну злагодженість діяльності студента та форм роботи викладача, вони повинні мати чітку, логічну комплексну схему, доповнювати одна одну. 3' являється можливість впровадження різних педагогічних методик і підходів: використання ділових, імітаційних ігор, ситуаційних задач, проблемних ситуацій, тренінгів, комп'ютерних навчально-контролюючих тестових завдань, що є необхідно під час практичної підготовки майбутніх фахівців, і що не вдається реалізувати протягом короткочасних занять (2 академічні години).

Протягом єдиного навчального дня викладач має можливість постійно відслідковувати та контролювати засвоєння матеріалу студентами. Завдяки цьому покращується можливість безпосереднього контакту “викладач-студент”, з'являється можливість постійного безпосереднього консультування, також викладач може здійснювати регулярний контроль за виконанням поставлених завдань, тобто з'являється можливість стійкішого зворотного зв'язку. Як наслідок, вирішується проблема втрати часу на контроль знань - у відсотковому вираженні час скорочується приблизно втричі $[6,7]$.

В університеті запроваджено щоденний електронний контроль знань студентів в системі “"Moodle", який проводиться напередодні практичного заняття з виставленням відповідної оцінки. Результати оцінювання студент може побачити відразу ж після закінчення тестового контролю [5].

При використанні методики “Сдиного дня” спрощується та оптимізується підготовка студентів до заняття, оскільки студентам потрібно підготувати одну навчальну дисципліну, замість двох-трьох, а це також підвищує рівень запам'ятовування і відтворення пройденого матеріалу як на практичних заняттях, так i на іспитах.

Не можна залишити поза увагою і економічний фактор, адже заняття у кожній групі студентів протягом всього робочого дня проводяться на одній кафедрі, що не вимагає переїздів між корпусами, а це зменшує транспортні витрати та економить час.

До впровадження методики “Сдиного дня” у 2006 році заняття проводились традиційно (2 академічні години) і завершувались о 17 годині, тривалість перерви між заняттями була 40 хвилин, оскільки студентам потрібно було переїжджати з кафедри на кафедру, які розташовані в різних частинах міста, що часто було причиною запізнення студентів на занят- 
тя, а завдяки методиці “Єдиного дня” навчальний день у студентів розпочинається о 9 годині і закінчується о 15.00, отже економиться 2 години, які можна використати на самопідготовку або відпочинок.

3 метою обгрунтування даної методики було проведено статистичні дослідження. Для оцінки ефективності використання методики “Единого дня” для теоретичної та практичної підготовки студентів у вивченні іноземної мови ми провели анкетування серед студентів 2 курсу Тернопільського державного медичного університету. В анкетуванні брали участь 204 студенти, найстаршому з яких 26 років, наймолодшому - 17, переважній кількості студентів 20-22 роки. Кількість осіб жіночої статті складала 44 \%.

Психологічний фактор

\begin{tabular}{|l|c|c|c|}
\hline \multicolumn{1}{|c|}{ Питання анкети } & так & ні & на 50 \% \\
\hline $\begin{array}{l}\text { Чи легко Вам сприймати } \\
\text { та відтворювати протягом } \\
\text { 6-7-годинного заняття } \\
\text { матеріал, що стосується } \\
\text { одного предмета? }\end{array}$ & & $6,7 \%$ & $46,1 \%$ \\
\hline $\begin{array}{l}\text { Чи легко Вам запам'ятову- } \\
\text { вати та відтворювати отри- } \\
\text { маний протягом одного } \\
\text { навчального дня матеріал? }\end{array}$ & $58,3 \%$ & $4,2 \%$ & $37,5 \%$ \\
\hline $\begin{array}{l}\text { Як Ви вважаєте, чи } \\
\text { підвищується ефектив- } \\
\text { ність запам'ятовування та } \\
\text { відтворення матеріалу, } \\
\text { поданого протягом } \\
\text { 6-7-годинного заняття? }\end{array}$ & $53,4 \%$ & $7,4 \%$ & $39,2 \%$ \\
\hline $\begin{array}{l}\text { Чи комфортно Ви себе } \\
\text { почуваєте протягом } \\
\text { 6-7-годинного заняття? }\end{array}$ & $43,3 \%$ & $23,6 \%$ & $33,2 \%$ \\
\hline
\end{tabular}

Лінгвістично-педагогічний фактор

\begin{tabular}{|l|c|c|c|}
\hline \multicolumn{1}{|c|}{ Питання анкети } & так & ні & на 50\% \\
\hline $\begin{array}{l}\text { Чи допомагає Вам } \\
\text { методика “Сдиного дня" } \\
\text { ефективно отримувати } \\
\text { мовні навички у профе- } \\
\text { сійному спілкуванні? }\end{array}$ & $72 \%$ & - & $28 \%$ \\
\hline $\begin{array}{l}\text { Чи допомагає Вам } \\
\text { методика “Сдиного дня” } \\
\text { ефективно готуватися до } \\
\text { усного спілкування з } \\
\text { хворим? }\end{array}$ & $69 \%$ & $2,8 \%$ & $28,2 \%$ \\
\hline $\begin{array}{l}\text { Чи вдається Вам } \\
\text { грунтовно оволодіти } \\
\text { матеріалом, отриманим за } \\
\text { допомогою методики } \\
\text { “Єдиного дня”? }\end{array}$ & $41,6 \%$ & $14,2 \%$ & $44,2 \%$ \\
\hline $\begin{array}{l}\text { Чи цікаво Вам вивчати } \\
\text { один предмет протягом 6- } \\
7 \text { годин? }\end{array}$ & $46,7 \%$ & $12,1 \%$ & $41,2 \%$ \\
\hline
\end{tabular}

Питання самопідготовки

\begin{tabular}{|l|c|c|c|}
\hline \multicolumn{1}{|c|}{ Питання анкети } & так & ні & на 50\% \\
\hline $\begin{array}{l}\text { Чи допомагає Вам } \\
\text { методика “Сдиного дня" } \\
\text { ефективно готуватися до } \\
\text { занять? }\end{array}$ & $82 \%$ & - & $18 \%$ \\
\hline $\begin{array}{l}\text { Чи допомагають Вам у } \\
\text { підготовці до занять } \\
\text { матеріали, викладені на } \\
\text { веб-порталі університету? }\end{array}$ & $64,1 \%$ & $33 \%$ & $2,9 \%$ \\
\hline $\begin{array}{l}\text { Чи складною для Вас } \\
\text { була інформація, } \\
\text { викладена у навчально- } \\
\text { методичних матеріалах? }\end{array}$ & $9,2 \%$ & $55,8 \%$ & $35 \%$ \\
\hline $\begin{array}{l}\text { Чи вважаєте Ви ефектив- } \\
\text { ним контроль знань за } \\
\text { системою “Мооде”? }\end{array}$ & $68 \%$ & $17,2 \%$ & $14,8 \%$ \\
\hline
\end{tabular}

\section{Методико-педагогічний фактор}

При використанні методики “Единого дня” важливими є доступність і якість навчальної інформації. Для того щоб вдосконалити викладання, в університеті впроваджено електронне навчання. Щоб допомогти студентам у підготовці до занять з іноземної або латинської мови, на веб-порталі університету подано велику кількість допоміжних матеріалів. Серед них: "Календарно-тематичний план проведення практичних занять”, "Матеріали для підготовки до практичних занять", “Методичні рекомендації для студентів”, аудіо- та відеоматеріали. Завдяки такому доробку студент завчасно ознайомлений з темою наступного заняття та має достатньо матеріалу для самостійної підготовки, що допоможе йому простіше і глибше засвоїти матеріал, який буде подаватися викладачем на занятті.

Під час проведення практичних занять використовується мультимедійне забезпечення. Це дає змогу викладачеві повноцінно проілюструвати навчальний матеріал.

Методика "Сдиного дня" передбачає 6-7-годинні заняття, що включають практичну роботу, семінарське обговорення вивченого матеріалу (на клінічних кафедрах, а оскільки іноземна мова $€$ новою для будького і опанувати іiї самостійно дуже важко, то це вимагає постійної практичної роботи і присутності викладача для допомоги студентам в опануванні мовних навичок) та тестовий контроль знань. Контроль може проводитися в трьох формах: оцінювання усної, письмової відповідей та практичної роботи. Напередодні практичного заняття студент має можливість пройти тестування в системі "Moodle", база якої включає по 150 (на спеціалізованих клінічних кафедpax - 250) завдань до кожного заняття, з них $60 \%$ 
тестів, $24 \%$ ситуаційних задач, $16 \%$ запитань до малюнків [2] .

Студенти починають заняття з виконання практичної роботи.

1. Організаційна частина заняття - до 5 хв.

2. Інструктаж студентів і розподіл груп для практичної роботи - до 10 хв.

3. Практична робота студентів - 120 хв.

4. Перерва - 30 хв.

5. Семінарське обговорення - 90 хв.

6. Перерва - 15 хв.

7. Письмовий контроль знань -30 хв.

8. Підведення підсумків заняття з оцінкою діяльності кожного студента - 15 хв $[9,10]$.

Якщо студент не пройшов тестовий контроль напередодні заняття, то він проходить його у письмовій формі після семінару. Завдання включає 24 тести, 3 них 5 ситуаційних задач та 5 питань до рисунків. Для тестового контролю знань розроблені критерії оцінки відповідей за 12-бальною шкалою, що дозволяс об' єктивно оцінювати результати [7, 8].

\begin{tabular}{|c|c|c|c|}
\hline Питання анкети & так & $\mathrm{Hi}$ & на $50 \%$ \\
\hline $\begin{array}{l}\text { Чи вважаєте Ви } \\
\text { ефективним постійний } \\
\text { контроль викладача для } \\
\text { опанування іноземної } \\
\text { мови професійного } \\
\text { спрямування? }\end{array}$ & $73,7 \%$ & $2,3 \%$ & $24 \%$ \\
\hline $\begin{array}{l}\text { Чи отримуєте Ви під час } \\
\text { заняття належну } \\
\text { допомогу викладача, яка } \\
\text { б сприяла опануванню } \\
\text { практичними мовними } \\
\text { навичками? }\end{array}$ & $69,1 \%$ & $16,1 \%$ & $14,8 \%$ \\
\hline
\end{tabular}

\section{Література}

1. Бігуняк Т. В. Використання інформаційних технологій у викладанні медичної біології/ Т. В. Бігуняк, Л. Т. Котляренко. - http://www.confcontact.com/20110225/pe4 bigunyak.php

2. Досвід Віденського медичного університету в реформуванні системи освіти. Перспективи співпраці / за ред. Л. Я. Ковальчука. - Тернопіль : ТДМУ, 2006. -290 с.

3. Зимова I. А. Педагогічна психологія : підручник / I. А. Зимова. - М. : Логос, 2004. -384 с.

4. Інтерактивні технології навчання / [авт.-упор. І. І. Дівакова]. - Тернопіль : Мандрівець, 2009. - С. 23 - 27.

5. Ковальчук Л. Я. Впровадження нової методики навчального процесу в Тернопільському державному медичному університеті імені І. Я. Горбачевського / Л. Я. Ковальчук // Медична освіта. - 2007. - № 2. - С. 16-20.

6. Марценюк В. П. Впровадження в навчальний процес комп’ютерних технологій / В. П. Марценюк// Впровадження засад Болонської системи освіти : український і зарубіжний

\begin{tabular}{|l|c|c|c|}
\hline \multicolumn{1}{|c|}{ Питання анкети } & так & ні & на 50\% \\
\hline $\begin{array}{l}\text { Чи отримуєте Ви } \\
\text { належну допомогу } \\
\text { викладача в процесі } \\
\text { виконання практичної } \\
\text { письмової роботи? }\end{array}$ & $73 \%$ & $12,8 \%$ & $85,8 \%$ \\
\hline $\begin{array}{l}\text { Чи допомагає Вам } \\
\text { постійне керівництво } \\
\text { викладача у засвоєнні та } \\
\text { застосуванні } \\
\text { професійної лексики? }\end{array}$ & $63,6 \%$ & $8,4 \%$ & $28 \%$ \\
\hline
\end{tabular}

Висновки. Досвід впровадження методики "Сдиного дня" показує його певні переваги. За час перебування на одній кафедрі протягом 6-7-ми годин студенти мають можливість виконати великий об'єм практичної роботи, виконати більш складні завдання, грунтовніше опанувати практичні мовні навички, більше часу приділити самостійній роботі та закріпленню навчального матеріалу.

При використанні методики “Единого дня” та дотриманні в процесі навчання певних умов, а саме: забезпечення позитивної та комфортної атмосфери в колективі для досягнення спільних цілей, усвідомлення учасниками важливості та цінності колективно зроблених умовиводів, можливості вільно висловити свою думку та вислухати свого товариша, сприйманні викладача як порадника або старшого товариша, відбувається формування та становлення студента як особистості.

Покращуються можливості безпосереднього контакту викладач-студент, краще консультування, стійкіший зворотний зв' язок.

Під час економічної кризи суттєвою перевагою для студентів $€$ зменшення транспортних витрат та економія часу.

досвід : матер. Всеукр. навч.-наук. конф., 14-15 травня 2007p., м. Тернопіль. - Тернопіль : Укрмедкнига, 2007.-С. 35-37.

7. Марценюк В. П. Концептуальне подходы к структуре информационной системы проверки знаний в медицинском образовании / В. П. Марценюк // Кибернетика и вычислительная техника. - 2009. - Вып. 156. - С. 18-27.

8. Мастеров Ю. І. Інтерактивні технології та їх впровадження в практичне навчання студентів медичного коледжу / Ю. І. Мастеров, В. О. Марциненко // Клінічна та експериментальна патологія. -2011. - Т. Х, № 3 (37). -С. 30-33.

9. Методичні рекомендації для викладачів щодо організації навчального процесу в ТДМУ. - Тернопіль : Укрмедкнига, 2006. -86 c.

10. Попадинець Г. О. Впровадження інноваційних технологій навчання в процес викладання гуманітарних дисциплін / Г. О. Попадинець // Медична освіта.-2007. - № 1. -C. $47-51$. 